\title{
PENGGUNAAN TEPUNG BIJI ALPUKAT DAN PENGARUHNYA TERHADAP KECERNAAN LEMAK KASAR DAN ENERGI METABOLIS RANSUM AYAM BROILER
}

(Use of Avocado Seed Meal And Effect in the Ration On Crude Fat Digestibilty And Energy Metabolism in Broiler Chickens)

\author{
Nurrohman, A. ${ }^{1}$, Yunianto, V. D., ${ }^{2}$ dan Mangisah, $I^{3}$ \\ 1) Mahasiswa Fakultas Peternakan Dan Pertanian Universitas Diponegoro \\ Kampus drh. Soejono Koesoemowardjojo Tembalang Semarang 50275 \\ Email : arif.nurrohman@hotmail.com \\ ${ }^{2,3)}$ Fakultas Peternakan dan Pertanian Universitas Diponegoro \\ Kampus drh. Soejono Koesoemowardjojo Tembalang Semarang 50275
}

Diterima : 15 Oktober 2015 Disetujui : 25 November 2015

\begin{abstract}
This research was aimed to identify and review the effect of avocado seed meal in the ration on crude fat intake, crude fat digestibility, energy intake, and true metabolizable energy. Ninety of Day Old Chick (DOC) Lohmann strain broiler chickens with an average of initial body weight of 41,38 $\pm 1,08 \mathrm{~g}$ were used in this research. Completely Randomized Design (CRD) was used in this research with 3 treatments and 5 replications, consisted of TO (control ration), $T 1$ (ration with 7,5\% avocado seed meal), and T2 (ration with $15 \%$ avocado seed meal). Parameters observed were crude fat intake, crude fat digestibility, energy intake dan true metabolizable energy. Results showed that utilization of avocado seed meal in broiler ration significantly effected $(P<0,01)$ on crude fat intake, crude fat digestibility and energy intake, and significantly affected $(P<0,05)$ the true metabolizable energy. In conclusion, the utilization of avocado seed meal in the ration on level 7,5\% did not decrease true metabolizable energy, but decreased crude fat intake, crude fat digestibility and energy intake.
\end{abstract}

Keyword: broiler chicken, crude fat intake, crude fat digestibility, energy intake, and true metabolizable energy.

\begin{abstract}
ABSTRAK
Penelitian ini bertujuan untuk mengetahui dan mengkaji pengaruh penggunaan tepung biji alpukat dalam ransum terhadap konsumsi lemak kasar, kecernaan lemak kasar, konsumsi energi dan energi metabolis murni. Materi yang digunakan dalam penelitian adalah ayam broiler unsex strain Lohmann sebanyak 90 ekor yang berumur 1 hari dengan bobot awal ratarata 41,38 $\pm 1,08$ g. Rancangan percobaan yang digunakan adalah Rancangan Acak Lengkap (RAL) dengan 3 perlakuan dan 5 ulangan. Ransum perlakuan meliputi T0 = ransum kontrol (tanpa tepung biji alpukat), $\mathrm{T} 1=$ ransum dengan 7,5\% tepung biji alpukat, $\mathrm{T} 2=$ ransum dengan $15 \%$ tepung biji alpukat. Parameter yang diamati adalah konsumsi lemak kasar, kecernaan lemak kasar, konsumsi energi dan energi metabolis murni. Hasil penelitian menunjukkan bahwa penggunaan tepung biji alpukat dalam ransum berpengaruh nyata $(\mathrm{P}<0,01)$ terhadap konsumsi lemak kasar, kecernaan lemak kasar dan konsumsi energi dan
\end{abstract}


ayam broiler, dan berpengaruh nyata $(\mathrm{P}<0,05)$ terhadap energi metabolis murni. Simpulan penelitian adalah penggunaan tepung biji alpukat dalam ransum pada level $7,5 \%$ tidak menurunkan energi metabolis murni, tetapi menurunkan konsumsi lemak kasar, kecernaan lemak kasar, dan konsumsi energi.

Kata kunci: broiler, konsumsi lemak kasar, kecernaan lemak kasar, konsumsi energi, energi metabolisme murni.

\section{PENDAHULUAN}

Ayam broiler merupakan ayam pedaging yang dipelihara dengan waktu yang relatif cepat $( \pm 35$ hari) dapat memproduksi daging dengan efisien. Daging ayam broiler dibutuhkan masyarakat untuk mencukupi kebutuhan akan daging dan harganya terjangkau. Populasi ayam broiler di Indonesia mencapai 1.344.191.000 (BPS, 2014). Produktifitas ayam broiler didukung dengan pakan yang berkualitas. Pakan merupakan salah satu faktor keberhasilan usaha ayam broiler mencapai $60-70 \%$ dari total produksi. Tingginya harga pakan menjadi salah satu kendala dalam usaha ayam broiler, sehingga perlu alternatif yang murah dan memiliki kuaitas yang baik untuk menekan biaya produksi, salah satunya yaitu biji alpukat.

Produksi buah alpukat di Indonesia pada tahun 2012 mencapai 294.200 ton (BPS, 2014). Biji alpukat mengandung energi metabolisme $3570 \mathrm{kkal} / \mathrm{kg}$ dan protein kasar 10,40\% lebih tinggi dibanding jagung yaitu kandungan energi metabolisme 3370 $\mathrm{kkal} / \mathrm{kg}$ dan protein kasar 8,70\%. Kandungan lemak kasar biji alpukat 5,81\%, serat kasar $6,11 \%$, Ca 0,70\%, dan P 0,21\% (Nelwida, 2009). Penggunaan biji alpukat diharapkan dapat mengurangi penggunaan jagung dimana porsi jagung dalam ransum mencapai 50-60\% sehingga biaya pakan menjadi murah. Pemakaian biji alpukat harus dibatasi karena mengandung tannin yang dapat menurunkan daya cerna, palatabilitas dan produktifitas ayam broiler.
Tannin dapat menyebabkan palatabilitas menurun sehingga menurunkan konsumsi ransum. Tannin menghambat kerja enzim pencernaan yang daapt menyebabkan pertambahan bobot badan menurun (Anita et $a l .$, 2012). Oleh karena itu, perlu dilakukan pengolahan terhadap biji alpukat untuk menurunkan kadar tannin menggunakan larutan kalsium hidroksida $\mathrm{Ca}(\mathrm{OH})_{2}$ dan perebusan menggunakan air panas. Suhirman et al. (2006) menyatakan bahwa $\mathrm{Ca}(\mathrm{OH})$ merupakan larutan basa dan tannin sebagai polifenol larut dalam air dan basa, sehingga tannin akan berkurang setelah polifenol yang terlarut dihilangkan dengan cara pencucian. Berdasarkan penelitian Wiryawan (1999) bahwa perendaman daun kaliandra dengan menggunakan larutan kapur tohor $(\mathrm{CaO}) 2 \%$ selama 30 menit mampu menurunkan kandungan tannin sebesar $48 \%$ serta dapat meningkatkan kecernaan protein $82,40 \%$.

Penurunan kadar tannin dalam ransum diharapkan mampu meningkatkan kecernaan nutrisi ransum (protein kasar, serat kasar, lemak kasar, dan energi metabolis) dan meningkatkan nilai manfaat ransum sehingga dapat meningkatkan produktifitas ayam briler. Tujuan penelitian ini adalah untuk mengetahui dan mengkaji penggunaan tepung biji alpukat yang telah diolah terhadap konsumsi lemak kasar, kecernaan lemak kasar, konsumsi energi dan energi metabolisme murni ransum. Manfaat dari penelitian ini diharapkan memberikan informasi tentang pemanfaatan biji alpukat sebagai sumber energi dalam ransum ayam broiler. 


\section{MATERI DAN METODE}

Materi

Materi yang digunakan dalam penelitian ini adalah 90 ekor anak ayam umur 1 hari DOC unsex strain Lohmann dengan bobot awal rata-rata 41,38 $\pm 1,08 \mathrm{~g}$. Komposisi dan kandungan nutrisi dalam ransum penelitian dapat dilihat pada Tabel 1 . Perlengkapan yang digunakan dalam penelitian ini antara lain kandang litter, kandang batteray, tempat pakan, tempat minum, timbangan digital, sekam, dab nampan.

\section{Metode}

Penelitian dimulai dengan persiapan kandang, pembuatan tepung biji alpukat, penyusunan ransum serta persiapan ternak dan peralatan yang digunakan pada penelitian. Pembuatan tepung biji yaitu biji alpukat diiris tipis menggunakan pisau. Kemudian biji alpukat direndam dengan larutan kalsium hidroksida $\mathrm{Ca}(\mathrm{OH})_{2}$ dengan perbandingan $200 \mathrm{~g}$ kalsium hidroksida dilarutkan dengan 1 liter air selama 30 menit. Biji alpukat yang sudah direndam kemudian dibilas dengan air bersih, selanjutnya direbus selama 30 menit. Biji alpukat yang sudah direbus, disaring dan dikeringkan dibawah sinar matahari sampai kering. Proses selanjutnya adalah membuat tepung biji alpukat dengan cara menggiling biji alpukat dengan grinder sampai halus.

Tahap pemeliharaan yaitu ayam broiler dipelihara selama 41 hari. Ayam divaksin ND melalui tetes mata pada umur 4 hari. Ayam broiler diberi pakan komersial selama 2 minggu. Umur 11-14 hari dilakukan adaptasi ransum perlakuan terhadap ayam broiler, sedangkan ayam broiler diberi ransum perlakuan $100 \%$ pada umur 15 hari dan dipindahkan dalam kandang petak. Pada umur 4 hari, ayam dilakukan vaksinasi ND melalui tetes mata untuk mencegah penyakit Newcastle Desease (ND).

Tahap pengambilan data dengan mengukur konsumsi ransum, dan kecernaan nutrien. Pengukuran kecernaan menggunakan metode total koleksi selama 4 hari. Selama total koleksi dilakukan pengukuran konsumsi ransum dengan menghitung pemberian ransum dikurangi sisa ransum. Ayam yang digunakan dalam total koleksi diambil secara acak dari setiap unit percobaan, masing-masing 1 ekor dimasukkan dalam kandnag batteray pada umur 38 hari dan dipuasakan selama 24 jam. Umur 39 hari dan 40 hari ayam diberi ransum yang telah dicampur dengan indikator $\mathrm{Fe}_{2} \mathrm{O}_{3}$ sebanyak 0,05\% dari jumlah ransum dan dilakukan penampungan menggunakan nampan yang telah dilapisi plastik. Penampungan dimulai ketika ekskreta ayam berubah warna menjadi merah. Umur 41 hari ayam diberi ransum tanpa indikator dan penampungan ekskreta selesai dilakukan ketika ekskreta sudah berubah menjadi normal atau tidak nampak berwarna merah. Selama penampungan, ekskreta disemprot dengan $\mathrm{HCl}$ 0,2 $\mathrm{N}$ setiap 2 jam sekali agar $\mathrm{N}$ eksreta tidak menguap. Ayam diberi air minum secara adlibitum. 
Tabel 1. Komposisi dan Kandungan Nutrisi Ransum Penelitian

\begin{tabular}{|c|c|c|c|}
\hline Bahan pakan & T0 & T1 & $\mathrm{T} 2$ \\
\hline & \multicolumn{3}{|c|}{---------------( } \\
\hline Jagung kuning & 59,00 & 51,50 & 44,00 \\
\hline Tepung biji alpukat & - & 7,50 & 15,00 \\
\hline Bungkil kedelai & 15,00 & 15,00 & 15,00 \\
\hline Bekatul & 12,00 & 12,00 & 12,00 \\
\hline PMM & 8,00 & 8,00 & 8,00 \\
\hline Tepung ikan & 5,00 & 5,00 & 5,00 \\
\hline Premix & 1,00 & 1,00 & 1,00 \\
\hline Jumlah & 100 & 100 & 100 \\
\hline \multicolumn{4}{|l|}{ Kandungan nutrien } \\
\hline Protein kasar $(\%)^{*}$ & 20,06 & 20,20 & 20,33 \\
\hline Energi Metabolis $(\mathrm{kkal} / \mathrm{kg}) * * * *$ & $3.079,00$ & $3.105,00$ & $3.132,00$ \\
\hline Lemak kasar (\%)* & 6,34 & 6,43 & 6,52 \\
\hline Serat kasar $(\%) * *$ & 5,12 & 5,24 & 5,67 \\
\hline Kalsium $(\%) * * *$ & 0,88 & 0,93 & 0,98 \\
\hline Fosfor $(\%) * * *$ & 0,55 & 0,54 & 0,54 \\
\hline Tanin $(\%)^{*}$ & 0,27 & 0,32 & 0,39 \\
\hline
\end{tabular}

Keterangan :

* Dianalisis di Lab. Ilmu Nutrisi dan Pakan Fakultas Peternakan dan Pertanian Universitas Diponegoro, Semarang.

** Dianalisis di Pusat Studi Pangan dan Gizi Universitas Gadjah Mada, Yogyakarta.

*** Berdasarkan Tabel Hartadi et al. (1980), Patrick and Scott (1982), dan Nelwida (2009).

**** Dianalisis di Lab. Ilmu Nutrisi dan Pakan Fakultas Peternakan dan Pertanian Universitas Diponegoro, Semarang. Perhitungan energi berdasarkan gross energi x 0,725 (NRC, 1994).

Pengukuran endogenus ekskreta ayam broiler dimulai pada umur 38 hari dengan dipuasakan selama 24 jam dan dilakukan penampungan ekskreta endogenus pada hari ke 39 selama 24 jam. Ekskreta yang telah ditampung kemudian dipisahkan dari rontokan bulu dan kotoran, kemudian ditimbang untuk mendapatkan berat basah ekskreta dan selanjutnya dijemur dibawah sinar matahari. Ekskreta yang sudah kering ditimbang untuk mendapatakan berat ekskreta berat kering udata kemudian ekskreta dihaluskan menggunakan blender. Ekskreta yang sudah halus dianalisis untuk mengetahui kadar lemak kasar dan energi metabolis ekskreta.

Parameter yang diamati pada penelitian ini yaitu konsumsi lemak kasar, konsumsi energi metabolis, kecernaan lemak kasar dan metabolisme energi murni. Rumus perhitungannya diuraikan sebagai berikut:

1. Konsumsi Lemak Kasar $=$ Konsumsi ransum (g) $x$ Kadar lemak ransum (\%)

2. Konsumsi Energi Metabolis = Konsumsi ransum $\mathrm{x}$ Kadar energi metabolis ransum $(\mathrm{Kkal} / \mathrm{kg})$

3. Kecernaan Lemak Kasar $=$

Lemak yang dikonsumsi (g) - Lemak dalam ekskreta $(\mathrm{g}) \times 100 \%$ Lemak yang dikonsumsi $(\mathrm{g})$

Keterangan:

Lemak yang dikonsumsi = Kadar lemak ransum $\mathrm{x}$ konsumsi ransum

Lemak dalam ekskreta = Kadar lemak Ekskreta $\mathrm{x}$ jumlah ekskrta 
4. Energi metabolis dihitung dengan rumus Sibbald (1976) yang disitasi oleh Mulyono et al. (2009)

$\operatorname{EMM}(\mathrm{kkal} / \mathrm{g})=\frac{(\text { GEf } \times \mathrm{A}-(\text { YEf } \times \mathrm{B}-\mathrm{YEc} \times \mathrm{C}))}{\mathrm{A}}$

Keterangan:

EMM : energi metabolis murni

GEf : energi bruto $(\mathrm{kkal} / \mathrm{kg})$

YEf : energi bruto ekskreta ayam yang diberi makan $(\mathrm{kkal} / \mathrm{kg})$

YEc : energi bruto ekskreta ayam yang dipuasakan (kakl/kg)

A : berat pakan yang diberikan $(\mathrm{g})$

B : berat ekskreta yang diberi makan $(\mathrm{g})$

C : berat ekskreta yang dipuasakan $(\mathrm{g})$

Rancangan percobaan yang digunakan Rata-rata konsumsi lemak kasar pada adalah rancangan acak lengkap (RAL) perlakuan T0, T1, dan T2 secara berturutdengan 3 perlakuan dan 5 ulangan dengan 6 turut yaitu 3,22 g/ekor/hari, 2,18 g/ekor/hari, ekor ayam tiap ulangan. Perlakuan meliputi dan 1,75 g/ekor/hari. Konsumsi lemak kasar T0: Ransum basal; T1: Ransum basal pada perlakuan T1 dan T2 lebih rendah subtitusi jagung dengan tepung biji alpukat dibandingkan dengan T0, hal ini dapat 7,5\% dan T2: Ransum basal subtitusi jagung disebabkan oleh konsumsi ransum yang dengan tepung biji alpukat 15\%. Data hasil rendah. Semakin rendah konsumsi ransum, penelitian diolah secara statistik dengan semakin rendah lemak yang dikonsumsi. Hal analisis ragam dan apabila hasil analisis ini sesuai dengan pendapat Meliandasari et menunjukkan pengaruh yang nyata maka al. (2014) menyatakan bahwa konsumsi dilakukan uji beda nilai tengah ganda ransum ayam broiler dapat dipengaruhi Duncan untuk mengetahui perbedaan antar beberapa faktor, diantaranya yaitu kualitas perlakuan.

\section{HASIL DAN PEMBAHASAN}

Hasil pengukuran terhadap konsumsi lemak kasar, kecernaan lemak kasar, konsumsi energi dan energi metabolis murni ditampilkan pada Tabel 2.

\section{Pengaruh Perlakuan Terhadap Konsumsi Lemak Kasar}

Hasil analisis statistik menunjukkan bahwa penggunaan biji alpukat berpengaruh sangat nyata $(\mathrm{p}<0,01)$ terhadap konsumsi lemak kasar. Dari Tabel 2 dapat diketahui bahwa penggunaan tepung biji alpukat dalam ransum menurunkan konsumsi lemak kasar. dan kuantitas ransum, aktifitas ternak, umur, suhu lingkungan, palatabilitas, kesehatan, suhu lingkungan dan tingkat produksi dan pengelolaannya.

Konsumsi lemak yang rendah dapat dipengaruhi oleh warna ransum yang lebih gelap akibat kandungan tannin dalam ransum. Tannin memiliki warna gelap sehingga menurunkan palatablitias ransum. Aris et al. (2006) menyatakan bahwa penurunan tingkat palatabilitas ransum dapat dipengaruhi oleh warna ransum yang lebih pekat, bau dan rasa yang tajam. Anita et al. (2012) menyatakan bahwa pemberian tepung daun teh dalam ransum menurunkan konsumsi ransum yang disebabkan adanya kandungan tannin dalam ransum, dimana semakin rendah konsumsi ransum seiring 
dengan peningkatan level pemberian tepung daun teh dalam ransum. Krisnan (2005) menyatakan bahwa rendahnya palatabilitas ransum dapat disebabkan oleh adanya tannin dalam ransum. Palatabilitas rendah menyebabkan konsumsi ransum rendah dan berdampak pada laju pertumbuhan yang rendah.

Tabel 2. Rata-rata konsumsi lemak kasar, konsumsi energi, kecernaan lemak kasar, dan energi metabolisme murni ransum

\begin{tabular}{lrrr}
\hline \hline \multirow{2}{*}{ Parameter } & \multicolumn{3}{c}{ Perlakuan } \\
\cline { 2 - 4 } & \multicolumn{1}{c}{ T0 } & \multicolumn{1}{c}{ T2 } \\
\hline $\begin{array}{l}\text { Konsumsi lemak kasar } \\
\text { (g/ekor/hr)* }\end{array}$ & $3,22^{\mathrm{a}}$ & $2,18^{\mathrm{b}}$ & $1,75^{\mathrm{b}}$ \\
Konsumsi energi (kkal/hr)* & $356,73^{\mathrm{a}}$ & $233,54^{\mathrm{b}}$ & $186,61^{\mathrm{b}}$ \\
Kecernaan lemak kasar $(\%)^{*}$ & $83,20^{\mathrm{a}}$ & $72,16^{\mathrm{b}}$ & $71,42^{\mathrm{b}}$ \\
$\begin{array}{l}\text { Energi metabolismemurni } \\
\text { (kkal/kg)** }\end{array}$ & $3.122,34^{\mathrm{a}}$ & $2.913,38^{\mathrm{ab}}$ & $2.793,71^{\mathrm{b}}$ \\
\hline
\end{tabular}
Keterangan: * Huruf berbeda pada nilai rata-rata menunjukkan perbedaan nyata $(\mathrm{P}<0,01)$.
**Huruf berbeda pada nilai rata-rata menunjukkan perbedaan nyata $(\mathrm{P}<0,05)$.

\section{Pengaruh Perlakuan Kecernaan Lemak Kasar}

Hasil analisis statistik menunjukkan bahwa penggunaan biji alpukat berpengaruh sangat nyata $(\mathrm{p}<0,01)$ terhadap kecernaan lemak kasar. Dari Tabel 2 dapat diketahui bahwa penggunaan tepung biji alpukat dalam ransum menurunkan kecernaan lemak kasar. Rata-rata kecernaan lemak kasar pada perlakuan T0, T1, dan T2 secara berturutturut yaitu 83,20\%, 72,16\%, dan 71,42\%. Kecernaan lemak kasar pada perlakuan T1 dan T2 lebih rendah dibandingkan dengan T0, hal ini dapat disebabkan oleh rendahnya konsumsi lemak kasar ransum ayam yang juga semakin menurun. Hal ini sesuai dengan pendapat Kiha et al. (2012) yang menyatakan bahwa pengukuran kecernaan lemak kasar berdasarkan konsumsi lemak dikurangi lemak dalam eksreta dibagi konsumsi lemak dikalikan 100 persen, semakin tinggi konsumsi lemak maka semakin tinggi pula kecernaan lemak. Sukaryana et al. (2011) menyatakan bahwa penentuan kecernaan dilakukan untuk mengetahui nutrien yang dapat diserap untuk kebutuhan pokok, pertumbuhan dan produksi. Kecernaan dapat dipengaruhi oleh tingkat pemberian pakan, spesies hewan, defisiensi zat makanan, pengolahan bahan pakan, pengaruh gabungan bahan pakan dan gangguan saluran pencernaan.

Rata-rata kecernaan lemak kasar T0, T1, dan T2 pada perlakuan secara berturutturut yaitu $83,20 \%, 72,16 \%$ dan $71,42 \%$. Nilai kecernaan ransum digunakan untuk mengetahui tingkat penyerapan nutrien dalam tubuh. Rendahnya nilai kecernaan akibat penggunaan tepung biji alpukat dapat disebabkan oleh kandungan tannin dalam ransum. Hal ini sesuai dengan pendapat Estiningdriati et al. (2009) yang menyatakan bahwa kandungan tannin dalam ransum dapat menghambat enzim pencernaan sehingga menurunkan utilitas nutriennya. Konsumsi ransum yang rendah menyebabkan ayam broiler kekurangan nutrien sehingga nutrien yang dikonsumsi tidak mencukupi kebutuhan untuk 
produktifitas. Sukaryana et al. (2011) menyatakan bahwa kecernaan dapat dipengaruhi oleh defisiensi zat makanan, pengolahan bahan pakan, dan gangguan saluran pencernaan.

Garam empedu sangat diperlukan unggas dalam pencernaan dan penyerapan lemak. Jika garam empedu ternak tidak mencukupi untuk mengemulsi dan mengarbsopsi lemak maka dapat menurunkan nilai kecernaan lemak kasar. Hal ini sesuai dengan pendapat Widodo (2002) yang menyatakan bahwa cairan empedu adalah suatu cairan garam yang mengandung kolesterol, fosfolipid lesitin, serta pigmen empedu. Garam-garam empedu (garam natrium dan kalium) dari asam glikokolat dan taurokolat dari cairan empedu yang berperan dalam pencernaan dan penyerapan lemak. Garam empedu dapat membantu dalam menciptakan suasana yang lebih alkalis dalam khim usus halus agar absorpsi berlangsung dengan lancar.

\section{Pengaruh Pelakuan Terhadap Konsumsi Energi}

Hasil analisis statistik menunjukkan bahwa penggunaan biji alpukat berpengaruh sangat nyata $(\mathrm{p}<0,01)$ terhadap konsumsi energi. Dari Tabel 2 dapat diketahui bahwa penggunaan tepung biji alpukat dalam ransum menurunkan konsumsi energi. Konsumsi energi pada perlakuan T1 dan T2 lebih rendah dibandingkan dengan $\mathrm{T} 0$, hal ini dapat disebabkan oleh rendahnya konsumsi ransum. Hal ini sesuai dengan pendapat Kayadoe dan Hartini (2009) yang menyatakan bahwa konsumsi energi dihitung berdasarkan konsumsi ransum dikalikan dengan energi metabolis dalam ransum. Selain konsumsi, warna ransum perlakuan yang lebih gelap juga mempengaruhi konsumsi ransum ayam broiler karena ayam broiler lebih suka terhadap warna yang terang dibanding warna yang gelap. Hal ini sesuai dengan pendapat Situmorang et al. (2013) yang menyatakan bahwa ayam broiler lebih menyukai pakan yang berwarna kuning dan tidak gelap. Nelwida (2009) menyatakan bahwa tannin mempunyai warna merah dan rasa kelat sehingga konsumsi ransum menurun seiring dengan semakin meningkatnya level penggantian jagung dengan biji alpukat baik yang direndam maupun yang tidak direndam dengan air panas.

Berdasarkan hasil penelitian menunjukkan bahwa penggunaan tepung biji alpukat menurunkan konsumsi energi. Ratarata konsumsi energi pada perlakuan T0, T1, dan T2 secara berturut-turut yaitu 356,73 $\mathrm{Kkal} / \mathrm{kg}, \quad 233,54 \quad \mathrm{Kkal} / \mathrm{kg}$ dan 186,61 $\mathrm{Kkal} / \mathrm{kg}$. Hal ini tidak sesuai dengan pendapat Kayadoe dan Hartini (2009) yang menyatakan bahwa konsumsi energi ayam broiler dapat mencapai 485,71 kkal.kg. Pada umumnya ayam meningkatkan konsumsi untuk memenuhi kebutuhan energinya, selain itu tingkat palatabilitas dapat merangsang ayam untuk meningkatkan konsumsinya.

Menurunnya konsumsi energi dapat disebabkan oleh tannin yang terkandung dalam ransum dan berpengaruh terhadap performa ayam broiler. Semakin tinggi konsumsi energi semakin besar peluang ayam broiler memanfaatkan energi untuk hidup pokok dan pertumbuhan lebih optimal. Suci dan Setiyanto (2001) menyatakan bahwa zat antinutrisi tannin dapat menyebabkan konsumsi ransum, kecernaan protein, penggunaan energi menurun sehingga pertumbuhan menjadi terhambat. Krisnan (2005) menyatakan bahwa kandungan tannin dalam ampas teh dapat menekan energi metabolis dan menurunkan konsumsi ransum sehingga pertambahan bobot hidup menjadi lebih rendah. 


\section{Pengaruh Perlakuan Terhadap Energi Metabolis Murni}

Hasil analisis statistik menunjukkan bahwa penggunaan biji alpukat berpengaruh sangat nyata $(p<0,05)$ terhadap energi metabolis murni. Dari Tabel 2 dapat diketahui bahwa energi metabolis murni pada $\mathrm{T} 1$ tidak berbeda nyata dengan T0, sedangkan T2 lebih rendah dibandingkan dengan T0 dan T1. Pada perlakuan T1 tidak berbeda nyata dengan $\mathrm{T} 0$, hal ini menunjukkan bahwa kandungan energi terhitung mencukupi kebutuhan meskipun konsumsi ransum lebih rendah dibandingkan dengan T0. Rendahnya energi metabolis murni pada T2 disebabkan oleh rendahnya konsumsi energi ransum ayam yang rendah. Meskipun energi terhitung lebih tinggi dibanding dengan $\mathrm{T} 0$ dan $\mathrm{T} 1$ tetapi konsumsi ransum rendah, sehingga kebutuhan energi tidak mencukupi. Hal ini sesuai dengan pendapat Mulyono et al. (2009) yang menyatakan bahwa konsumsi energi metabolis diperoleh dari perkalian antara energi metabolis dengan konsumsi ransum, semakin tinggi konsumsi ransum peluang konsumsi energi semakin semakin tinggi. Kiha et al. (2012) yang menyatakan bahwa konsumsi ransum menurun yang semakin berkurang menyebabkan konsumsi nutrien sumber energi juga ikut berkurang dimana sumber energi dapat bersumber dari konsumsi karbohidrat, lemak dan protein.

Berdasarkan Tabel 2 menunjukkan bahwa penggunaan tepung biji alpukat dalam ransum menurunkan energi metabolis murni. Rata-rata energi metabolis murni pada perlakuan T0, T1, dan T2 dalam penelitian ini berturut-turut 3.122,34 Kkal/kg, 2.913,48 $\mathrm{Kkal} / \mathrm{kg}$, dan $2.793,71 \mathrm{Kkal} / \mathrm{kg}$. Hal ini sesuai dengan pendapat Ichwan (2003) yang menyatakan bahwa kebutuhan energi ayam broiler periode starter sebesar 2800-3100 $\mathrm{kkal} / \mathrm{kg}$ pada tingkat protein 21-23\%, sedangkan kebutuhan energi periode finisher sebesar $2900-3200 \mathrm{kkal} / \mathrm{kg}$ pada tingkat protein 19-21\%. SNI (2006) menyatakan bahwa kebutuhan energi ayam broiler periode starter dan fisiher yaitu minimal $2900 \mathrm{Kkal} / \mathrm{kg}$.

Energi metabolis yang rendah dapat disebabkan oleh kecernaan lemak kasar yang rendah. Energi dapat diperoleh dari metabolisme karbohidrat, lemak dan protein. Hal ini sesuai dengan pendapat Wahju (1997) yang menyatakan bahwa zat-zat makanan yang menjadi sumber energi adalah karboidrat, lemak dan protein. Berdasarkan hasil penelitian terhadap kecernaan protein (Nelwida, 2009) penggunaan tepung biji alpukat menurunkan kecernaan protein akibat semakin tinggi level penggunaan tepung biji alpukat. Protein merupakan salah satu sumber energi bagi ternak. Rendahnya kecernaan dapat dipengaruhi oleh kandungan tannin dalam ransum karena tannin bersifat mengikat protein sehingga penyerapan protein terhambat. Widodo (2002) menyatakan bahwa tannin mempunyai kemampuan mengendapkan protein, karena tannin mengandung sejumlah kelompok fungsional ikatan yang kuat dengan molekul protein dan menghasilkan ikatan silang yang besar dan kompleks yaitu protein tannin. Wahyuni et al. (2008) menyatakan bahwa tannin dalam ransum mempengaruhi metabolisme zat gizi dalam tubuh karena dapat menghambat kerja enzim amilase, lipase dan protease sehingga menyebabkan penurunan penyerapan gizi yang dapat digunakan sebagai sumber energi dan mempengaruhi nilai energi metabolisnya.

Kandungan tannin dalam ransum mempengaruhi tingkat penyerapan nutrien karena tannin mampu mengikat protein sehingga proses abdosrpsi protein jadi terhambat. Kandungan tannin dalam ransum 
penelitian yaitu $0,27 \%$ (T0), 0,32\% (T1), dan 0,39 (T2). Tingginya kandungan tannin semakin meningkat seiring dengan meningkatnya kandungan tepung biji alpukat dalam ransum. Widodo (2005) menyatakan bahwa pemberian pakan yang mengandung tannin sebesar 0,33 persen tidak membahayakan. Akan tetapi apabila kandungan tannin dalam pakan mencapai 0,5 persen atau lebih dapat menekan pertumbuhan ayam karena tannin menekan retensi nitrogen dan mengakibatkan menurunnya daya cerna asam-asam amino yang seharusnya dapat diserap oleh vili-vili usus dan dimanfaatkan untuk pertumbuhan dan perkembangan jaringan tubuh.

\section{KESIMPULAN}

\section{Kesimpulan}

Berdasarkan hasil penelitian dapat disimpulkan bahwa penggunaan tepung biji alpukat level $7,5 \%$ tidak menurunkan energi metabolis murni, tetapi menurunkan konsumsi lemak kasar, kecernaan lemak kasar dan konsumsi energi.

\section{Saran}

Perlu pengkajian yang lebih mendalam tentang penggunaan tepung biji alpukat level dibawah atau di bawah 7,5\% dan pengaruh terhadap energi metabolis murni, konsumsi lemak kasar, dan kecernaan lemak kasar.

\section{DAFTAR PUSTAKA}

Anita, W. Y., I. Astuti, dan Suharto. 2012. Pengaruh pemberian tepung daun teh tua dalam ransum terhadap performan dan persentase lemak abdominal ayam broiler. Tropical Animal Husbandry. 1 (1) : 1-6.

Aris, S., E. Mirwandhono, dan Emmyliam. 2006. Pemanfaatan tepung temulawak (Curcuma xanthorriza Roxb.) dan molases dalam ransum terhadap performa dan income over feed cost (IOFC) itik peking umur 156 hari. Jurnal Agribisnis Peternakan. 2 (2) : 67-71.

Badan Standarisasi Nasional. Pakan Ayam Ras Pedaging (Broiler Finisher). SNI 01 - 3931-2006.

Badan Standarisasi Nasional. Pakan Ayam Ras Pedaging (Broiler Starter). SNI 01 - 3930-2006.

Estiningdriati, I., U. Atmomarsono, L. Jauhari, dan A. L. Nuary. 2009. Penggunaan tempe sorghum dalam ransum dan pengaruhnya terhadap penampilan produksi ayam broiler. Seminar Nasional Kebangkitan Peternakan : 682-687.

Ichwan. 2003. Membuat Pakan Ayam Ras Pedaging. Cetakan I. PT Agromedia Pustaka Utama, Jakarta.

Kayadoe, M., dan S. Hartini. 2009. Kemampuan konsumsi ayam pedaging pada ransum komersiil yang disubstitusi dengan solid kelapa sawit fermentasi. Jurnal Ilmu Peternakan. 4 (1) : 13-19.

Kiha, A. F., W. Murningsih, dan Tristiarti. 2012. Pengaruh pemeraman ransum dengan sari daun pepaya terhadap kecernaan lemak dan energi metabolis ayam broiler. Animal Agricultural Journal. 1 (1) : 265-276.

Krisnan, R. 2005. Pengaruh pemberian ampas teh (Camellia sinensis) 
fermentasi dengan aspergillus niger pada ayam broiler. JITV. 10 (1) : 1-5.

Meliandasari, D., B. Dwiloka, dan E. Suprijatna. 2014. Profil perlemakan darah ayam broiler yang diberi pakan tepung daun kayambang (Salvinia molesta). Jurnal Ilmu-Ilmu Peternakan. 24 (1) : 45-55.

Mulyono, R., Murwani, dan F. Wahyono. 2009. Kajian penggunaan probiotik Saccharomyces cereviceae sebagai alternatif aditif antibiotik terhadap kegunaan protein dan energi pada ayam broiler. J.Indon.Trop.Agric. $\mathbf{3 4}$ (2) : 145-151.

Nelwida. 2009. Efek Penggantian jagung dengan biji alpukat yang direndam air panas dalam ransum terhadap retensi bahan kering, bahan organik dan protein kasar pada ayam broiler. Jurnal Ilmiah Ilmu-Ilmu Peternakan. 12 (1) : 50-56.

Situmorang, N. A., L. D., Mahfudz, dan U. Atmomarsono. 2013. Pengaruh pemberian tepung rumput laut (gracilaria verrucosa) dalam ransum terhadap efisiensi penggunaan protein ayam broiler. Animal Agricultural Journal. 2 (2) : 49-56.

Suci, D. W., dan H. Setiyanto. 2001. Pengaruh pengolahan sorgum terhadap penurunan kadar tanin dan pengukuran energi metabolis. Seminar Nasional Teknologi Peternakan dan Veteriner : 647-651.

Suhirman, S., H. EA, dan Lince. 2006. Pengaruh penghilang tanin dari jenis pala terhadap sari buah pala. Bul. Littro. 17 (1) : 39-52.
Sukaryana, Y., U. Atmomarsono, V. D. Yunianto dan E. Suprijatna. 2011. Peningkatan nilai kecernaan protein kasar dan lemak kasar produk fermentasi campuran bungkil inti sawit dan dedak pagi pada broiler. JITP. 1 (3) : 167-172.

Wahju, J. 1997. Ilmu Nutrisi Unggas. Gadjah Mada University Press, Yogyakarta.

Wahyuni, H. I., R. I. Pujiningsih., dan P. W. Sayekti. 2008. Kajian nilai energi metabolis biji sorghum melalui teknologi sangrai pada ayam petelur periode afkir. Agripet. 8 (1) : 25-30.

Widodo, W. 2002. Nutrisi dan Pakan Unggas Kontekstual. Fakultas Peternakan Universitas Malang, Malang.

Widodo, W. 2005. Tanaman Beracun dalam Kehidupan Ternak. Fakultas Peternakan Universitas Muhammadiyah Malang, Malang.

Wiryawan, K.G. 1999. Upaya pengurangan kadar tanin dalam daun kaliandra (Calliandra callothyrsus ) dengan menggunakan larutan kapur tohor $(\mathrm{CaO})$ dan uji kecernaannya secara in-vitro. Media Peternakan. 22 (2) : 52-59.

www.bps.go.id. 2014. Populasi Ternak, 2000-2014.

www.bps.go.id. 2014. Produksi Buahbuahan dan Sayuran Tahunan di Indonesia. 